\title{
Subarachnoid haemorrhage mimicking acute myocardial infarction
}

\author{
François Delelis, ${ }^{1}$ Gauthier Calais, ${ }^{2}$ Pierre-Vladimir Ennezat, ${ }^{3}$ Arnaud Delebarre, ${ }^{4}$ Riadh Rihani, ${ }^{1}$ \\ Jean-Michel Lemahieu, ${ }^{1}$ Pierre Cornaert, ${ }^{1}$ Sylvestre Maréchaux ${ }^{1}$
}

${ }^{1}$ Cardiology Department, GHICL/CH St Philibert/Faculté libre de médecine de Lille, Lomme, France;

${ }^{2}$ Neurology Department, GHICL/CH St Philibert/Faculté libre de médecine de Lille, Lomme, France;

${ }^{3}$ Cardiology Department, Institut Cardiovasculaire Paris Sud/Hopital privé Jacques Cartier, Massy, France;

${ }^{4}$ Radiology Department, GHICL/CH St Philibert/Faculté libre de médecine de Lille, Lomme, France

Correspondence to Dr Sylvestre Maréchaux, sylvestre.marechaux@yahoo.fr

\section{DESCRIPTION}

A 54-year-old obese woman with a history of hypertension dialed ambulance service for headache and vomiting. EKG found diffuse ST segment elevation (figure 1A). Prehospital management consisted of intravenous aspirin, oral antiplatelet therapy (prasugrel) and subcutaneous low-molecular-weight heparin. She was transferred in our intensive care unit. Echocardiography showed impaired left ventricular ejection fraction (30\%) with apical dysfunction but preserved basal function (figure 1B-D). Coronary angiography showed normal epicardial coronary arteries (figure 1E,F); left ventriculography showed systolic ballooning of the apex and hypercontraction of the basal segment (figure $1 \mathrm{G}, \mathrm{H}$ ). The patient presented suddenly consciousness disturbances then coma requiring ventilatory support. Encephalic CT scan showed diffuse subarachnoid haemorrhage with mass effect on the brain stem in the posterior fossa (figure 1I,J). The evolution was rapidly unfavourable and the patient died in $1 \mathrm{~h}$. Myocardial dysfunction without coronary involvement may occur in acute cerebral diseases. The most encountered form is the left ventricular apical ballooning, as in the present case, named Takotsubo cardiomyopathy. ${ }^{1}$ Direct myocyte injury-mediated myocardial contractile dysfunction is likely to be the consequence of an adrenergic storm in the setting of neurologic disorders. ${ }^{2}$ This cardiomyopathy may mimick an acute coronary syndrome (ACS) with precordial pain, various changes of the ST segment, T wave or QTc interval on electrocardiogram, and raised cardiac enzymes. In the present case, ST segment elevation was found in the absence of chest pain and without mirror abnormalities. In the absence of a clinical context of ACS, potentially harmful antiplatelet and anticoagulation therapies should be delayed until coronary artery disease involvement has been proven.

Acknowledgements The authors thank Régine Mahieu for technical help

Competing interests None.

Patient consent Obtained.

\section{REFERENCES}

1. Dote K, Sato H, Tateishi H, et al. Myocardial stunning due to simultaneous multivessel coronary spasms: a review of 5 cases. J Cardiol 1991;21:203-14.

2. Ennezat PV, Pesenti-Rossi D, Aubert JM, et al. Transient left ventricular basal dysfunction without coronary stenosis in acute cerebral disorders: a novel heart syndrome (inverted Takotsubo). Echocardiography 2005;22:599-602.

This pdf has been created automatically from the final edited text and images.

Copyright 2012 BMJ Publishing Group. All rights reserved. For permission to reuse any of this content visit http://group.bmj.com/group/rights-licensing/permissions.

BMJ Case Report Fellows may re-use this article for personal use and teaching without any further permission.

Please cite this article as follows (you will need to access the article online to obtain the date of publication).

Delelis F, Calais G, Ennezat PV, Delebarre A, Rihani R, Lemahieu JM, Cornaert P, Maréchaux S. Subarachnoid haemorrhage mimicking acute myocardial infarction. BMJ Case Reports 2012;10.1136/bcr.11.2011.5134, Published XXX

Become a Fellow of BMJ Case Reports today and you can:

- Submit as many cases as you like

- Enjoy fast sympathetic peer review and rapid publication of accepted articles

- Access all the published articles

- Re-use any of the published material for personal use and teaching without further permission

For information on Institutional Fellowships contact consortiasales@bmjgroup.com

Visit casereports.bmj.com for more articles like this and to become a Fellow

Keep up to date with all published cases by signing up for an alert (all we need is your email address) http://casereports.bmj.com/cgi/alerts/etoc 


\section{BMJ Case Reports}

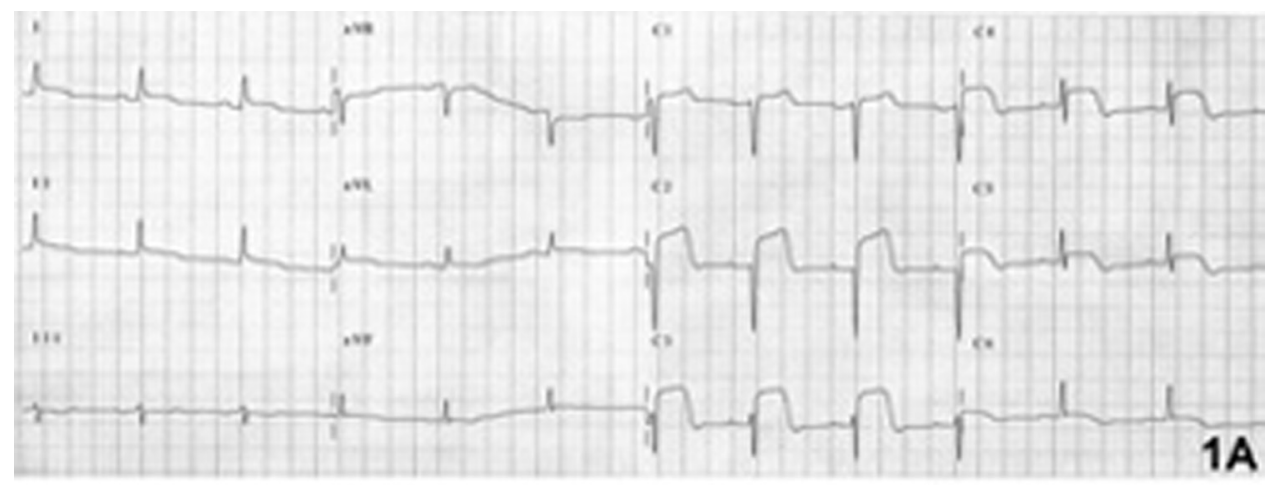

Figure 1 ST segment elevation in the antero-lateral leads (A), left ventricular apical dysfunction (B and C, LV end diastolic and end systolic volumes in apical four-chamber views), decreased LV apical longitudinal strain (D, bull eye of regional LV strains), normal coronary arteries (E right coronary artery, $\mathrm{F}$ left coronary artery), left systolic ballooning of the apex and hypercontraction of the basal segments at ventriculography ( $\mathrm{G}$ and $\mathrm{H}$, white arrows), and diffuse subarachnoid haemorrhage with mass effect on the brain stem in the posterior fossa (I and J, black arrows). 